Active Psychology and the Welfare and Progress of Man

Notes on the Establishment of a Non-Medical Practical Psychology. By G. E. Witt. Pp. iii +88 . (London: H. K. Lewis and Co., Ltd., 1947.) 7s. 6d.

$\mathrm{T}$ HE late Dr. G. E. Witt was a pupil of Kraepelin and Bonhoeffer, and it might have been expected that he would produce an authoritative book. Unfortunately, this present one does not fulfil its grandiose title, and is disappointing. A foreword states that it is "A collection of thoroughly worked through and paragraphised notes. These notes or paragraphs have kept their independency. The sequence is fortuitous." This places a strain on the reader. The foreword admits "This mode of presentation has its advantages and its disadvantages. The disadvantages can be reduced by an index." Perhaps an index will be a part of the second volume ; none is provided in the present one.

Dr. Witt's views show that he felt that psychiatry should be expanded into 'active psychology', which is defined in paragraph 2 as "An applied psychology. Resulting from certain perceptions it is a practical method of working psychologically upon the human mind." But unfortunately it continues by stating: "The method, and its foundation, will be explicitly dealt with in another volume". It seems that Dr. Witt believed that by emancipating psychiatry from general medicine and by widespread training in 'active psychology' a revolution would occur in social life as well as treatment.

The style of this book is repetitive, the exposition disjointed and difficult to follow, and much of the matter is dependent on a further volume. The printing and paper are good, and the book is paper bound.

\section{Using and Managing Soils}

By Prof. A. F. Gustafson. (McGraw-Hill Rural Activities Series.) Pp. xii +420. (New York and London: McGraw-Hill Book Co., Ine., 1948.) $17 s$.

$7 \mathrm{HE}$ object of this book is to provide the intelligent American farmer, smallholder or gardener with a short aceount of the scientific principles of soil management. The author, who has written several well-known books, is professor of soil technology at Cornell University, and among the topies he discusses the following are most relevant to British conditions : cultivation, drainage, maintenance of fertility, the best ways of using farmyard manure and green manures, and the proper use of fertilizers and crop rotations. He gives many examples of management; but, for obvious reasons, these mainly refer to the agriculture of the north-eastern and middlewestern United States. Thus the book is unsuitable for the corresponding practical man or student in Britain. On the other hand, lecturers in erop husbandry at farm institutes and agricultural colleges in Britain will easily be able to pick out from the discussion the principles applicable to British agriculture.

The great difficulty in writing any book such as this is to combine simplicity with accuracy and conciseness with adequacy of presentation. There are a number of places where the reviewer is not in full agreement either with the adequacy or accuracy of the seience, or with what has been omitted or included. But his main criticism is that at several places the general principles are not brought out as clearly as they should be, so that no indication is there given of the generality of the results stated, or the reasons for them.

The book is very well produced, is copiously illustrated and contains many tables of experimental results.

E. W. RUSSELL

Discharge Lamps for Photography and Projection By H. K. Bourne. Pp. xv +424 . (London : Cnapman and Hall, Ltd., 1948.) 36s. net.

A BOOK written by a research worker, which A deals with the subject in which he has specialized for a number of years, is always worthy of attention, and Mr. H. K. Bourne's "Discharge Lamps" is no exception to this general rule. The title is perhaps somewhat misleading, as there is a not inconsiderable section dealing with incandescent filament lamps and carbon arcs, as well as a section later in the book dealing with photographic flash lamps of the aluminium foil or wire type.

There are many people, whether belonging to the class of student or lecturer or potential user, who have not been in a position to follow the rapid developments of the last two decades in the field of light sources, to whom this book will prove valuable for reference purposes. Account has obviously been taken of most of the important papers whicn have been published on this subject as well as of the patent literature.

Mr. Bourne's book contains much data and information published for the first time, and it can be strongly recommended as an authoritative work covering a large section of the field of special-purpose illuminants. It gives in conveniently summarized form data on the electrical and luminous properties of most types of electric discharge lamp at present available. The sections dealing with applications will no doubt stimulate further interest in these relatively new light sources.

J. N. ALdington

\section{The Hunting Wasp}

By John Crompton. Pp. 255. (London and Glasgow : Wm. Collins, Sons and Co., Ltd., 1948.) 10s. 6d. net.

THIS book may be deseribed as a popularization anew of the writings of Fabre and the Peckhams on the habits of the solitary wasps, enlivened by a number of personal anecdotes not always about insects, the whole written in a vivid and racy style which makes for easy reading. The author's manner may be sufficiently illustrated by his description of the wasps' nest in winter. "The long low-ceilinged halls echo vacantly. The cradles in their thousands lie empty. Vermin creep in : the mouse, the earwig, and the beetle keep the courts where Vespa gloried and drank deep".

The subject is presented in terms of an unblushing anthropomorphism; the intelligence of insects is taken for granted, but there is criticism and a selfreliant philosophy of the robust common-sense variety to be expected from a man who has knocked about the world.

A number of mis-spellings and small errors of fact do not detract seriously from a very readable book. But in justice to the entomologists of the Ministry of Agriculture, who have been conducting a well-planned and highly successful campaign against the Colorado potato beetle, it may be pointed out that it was not the British Government "frightened by the threatened invasion" which offered a reward of $£ 10$ for every Colorado beetle; that ill-conceived measure came from a newspaper office. V. B. WigGLESWORTH 